\title{
Changes in mRNA expression of arcuate nucleus appetite-regulating peptides during lactation in rats
}

\author{
Yoshihiro Suzuki, Keiko Nakahara, Keisuke Maruyama, Rieko Okame, Takuya Ensho, \\ Yoshiyuki Inoue and Noboru Murakami
}

Department of Veterinary Physiology, Faculty of Agriculture, University of Miyazaki, Miyazaki 889-2192, Japan
Correspondence should be addressed to N Murakami Email a0d201@cc.miyazaki-u.ac.jp

\begin{abstract}
The contribution of hypothalamic appetite-regulating peptides to further hyperphagia accompanying the course of lactation in rats was investigated by using PCR array and real-time PCR. Furthermore, changes in the mRNA expression for appetite-regulating peptides in the hypothalamic arcuate nucleus (ARC) were analyzed at all stages of pregnancy and lactation, and also after weaning. Food intake was significantly higher during pregnancy, lactation, and after weaning than during non-lactation periods. During lactation, ARC expression of mRNAs for agouti-related protein (AgRP) and peptide YY was increased, whereas that of mRNAs for proopiomelanocortin (POMC) and cholecystokinin (CCK) was decreased, in comparison with non-lactation periods. The increase in AgRP mRNA expression during lactation was especially marked. The plasma level of leptin was significantly decreased during the course of lactation, whereas that of acyl-ghrelin was unchanged. In addition, food intake was negatively correlated with the plasma leptin level during lactation. This study has clarified synchronous changes in the expression of many appetite-regulating peptides in ARC of rats during lactation. Our results suggest that hyperphagia during lactation in rats is caused by decreases in POMC and CCK expression and increases in AgRP expression in ARC, the latter being most notable. Together with the decrease in the blood leptin level, such changes in mRNA expression may explain the further hyperphagia accompanying the course of lactation.
\end{abstract}
Key Words
- lactation
- hypothalamus
- arcuate nucleus
- AgRP
- $\mathrm{POMC}$
- C3
- PYY
- leptin

Journal of Molecular Endocrinology (2014) 52, 97-109

\section{Introduction}

In lactating mammals, many physiological changes occur in order to ensure milk production for suckling. These include development of the mammary glands, and increases in the plasma levels of prolactin, the hormone that triggers milk production, and oxytocin, the hormone that triggers milk ejection, in response to the suckling stimulus (Higuchi et al. 1985, Lee et al. 1989). Growth hormone $(\mathrm{GH})$ also plays an important role in milk production (Flint et al. 1992, Etherton \& Bauman 1998). Lactation in the mammary gland also markedly increases the nutrient requirement of female mammals to a level that exceeds that of the whole body in non-lactating females (Vernon \& Flint 1984, Wade \& Schneider 1992). As a consequence, food consumption increases several fold during lactation (Asakuma et al. 2004, Woodside et al. 2012). Furthermore, daily food consumption increases http://jme.endocrinology-journals.org DOI: 10.1530/JME-13-0015
(C) 2014 The authors Published by Bioscientifica Ltd Printed in Great Britain
This work is licensed under a Creative Commons Attribution 3.0 Unported License. 
with milk yield and pup growth (Woodside 2007). Although rats feed mainly at night, lactating females eat as much in the daytime as they do at night (Munday \& Williamson 1983). In order to induce this change in feeding behavior, various alterations occur in the CNS.

The hypothalamus has an important role in appetite regulation. For example, damage to the ventromedial hypothalamus causes hyperphagia, whereas destruction of the lateral hypothalamus results in profound anorexia (Hetherington \& Ranson 1940, Anand \& Brobeck 1951). The control of appetite by the hypothalamus involves many peptides. Increases in the protein levels of neuropeptide Y (NPY) and agouti-related protein (AgRP) trigger an orexigenic response, whereas increases in the levels of proopiomelanocortin (POMC) and cocaine- and amphetamine-regulated transcript trigger an anorexigenic response (Ellacott \& Cone 2004). Especially, the hypothalamic arcuate nucleus (ARC), one of the crucial sites in the hypothalamus regulating appetite and body weight, contains both NPY/AgRP and POMC neurons. In addition, the neurons in the ARC send axons to the paraventricular nucleus, dorsomedial nucleus, and lateral hypothalamic area (Kawano et al. 2002, Ellacott \& Cone 2004). The expression of appetite-related genes is regulated by a number of endocrine substances, which including leptin, acyl-ghrelin, complement C3 (C3), cholecystokinin (CCK), galanin, hypocretin, and peptide YY (PYY) (Smith \& Ferguson 2008, Ricklin et al. 2010, Parker \& Bloom 2012).

Leptin is an anorexigenic hormone primarily secreted from white adipose tissue (WAT). In addition, synthesis of leptin occurs in brown adipose tissue, liver, skeletal muscle, the gastric fundus, placenta, ovary, mammary epithelial cells, bone marrow, pituitary gland, and hypothalamus (Morash et al. 1999). The effects of leptin are mediated by binding to OBRb (Tartaglia et al. 1995, Lee et al. 1996). Leptin is implicated in the regulation of energy metabolism and energy expenditure (Cohen et al. 2002, Chilliard et al. 2005), food intake (Pelleymounter et al. 1995, Levin et al. 1996), and reproduction (Clarke \& Henry 1999). These effects are exerted via the CNS and in order for this to occur peripheral leptin must be transported across the blood-brain barrier (BBB) and/or arrive in the solitary tract nucleus (NTS) via the vagal afferent pathway (Buyse et al. 2001). For hypophagia to occur, leptin increases the hypothalamic expression of POMC mRNA and decreases that of NPY and AgRP mRNAs (Schwartz et al. 1996, 1997, Thornton et al. 1997).

In lactating female rats, it has been reported that peripheral prolactin, PYY, and CCK levels are increased compared with those in non-lactating female (Lee et al.
1989, Lindén et al. 1990, Taylor et al. 2009). Many studies have demonstrated that lactation in rats does not change, nor reduce, acyl-ghrelin levels in blood (Abizaid et al. 2008, Taylor et al. 2009). The blood leptin level in lactating rats was shown to be lower than that in non-lactating females (Pickavance et al. 1998). Furthermore, our previous study demonstrated that i.v. administration of leptin to lactating rats did not suppress food intake, suggesting that the hyperphagia shown by lactating rats may be related to a decline in the anorexigenic effect of leptin (Suzuki et al. 2010). These observations raise the possibility that these changes in peripheral hormones levels are involved in central feeding control on the hyperphagia during lactation.

Many researchers have investigated the effects of leptin, ghrelin, prolactin, CCK, and sucking stimulation on hypothalamic appetite-regulating peptides during lactation (Chen et al. 2008, Crowley et al. 2007, Woodside 2007, Woodside et al. 2012, Cui et al. 2011). However, the factors directly mediating the continued hyperphagia accompanying the course of lactation have not been fully elucidated. The aim of this study, therefore, was to clarify this issue through a global analysis of mRNA expression for hypothalamic appetite-regulating peptides and of peripheral hormone levels at two different phases of lactation: early (day 5) and late (day 15).

\section{Materials and methods}

\section{Animals}

All experiments were conducted in accordance with the Japanese Physiological Society's guidelines for animal care. Female Wistar rats aged 13-18 weeks were used. The rats were housed under constant temperature $(23 \pm$ $1{ }^{\circ} \mathrm{C}$ ) and a $12 \mathrm{~h}$ light: $12 \mathrm{~h}$ darkness lighting regime (light on at $0700 \mathrm{~h}$ ) with free access to food and water. The female rats were mated on the day of proestrus at the age of 10-11 weeks, and the day after mating was counted as day 1 of pregnancy. Rats on day 14 of pregnancy were used in Experiment 3. Lactating rats were mated at 9-10 weeks of age and housed singly with their litters at 13-16 weeks of age. The litter size was adjusted to ten pups (five males and five females) at birth. The day of parturition was counted as day 0 of lactation. Rats were used on day 5 or 15 of lactation. Pups were weaned on day 21 of lactation. The day of weaning was counted as day 0 after weaning. Rats of day 9 after weaning were used in Experiment 3. The control (non-lactating) rats were virgin, at the diestrus stage, and the same age as the lactating rats.

Published by Bioscientifica Ltd 
Experiment 1: changes in mRNA expression for hypothalamic appetite-regulating peptides in lactating and non-lactating rats

The body weights and 24-h food intakes of lactating and non-lactating rats were measured at $1000 \mathrm{~h}$, and the animals were then decapitated to obtain blood and brain samples. Abdominal WAT weights were also measured. Blood samples were placed in a tube containing EDTA$2 \mathrm{Na}(2 \mathrm{mg} / \mathrm{ml}$ blood) and aprotinin $(500 \mathrm{KIU} / \mathrm{ml}$ blood $)$ and centrifuged at $4{ }^{\circ} \mathrm{C}$. To determine the plasma concentration of acyl-ghrelin, plasma was immediately mixed with a $1 / 10$ volume of $1 \mathrm{M} \mathrm{HCl}$. The brain samples were immediately divided into hypothalamic blocks and total RNA was extracted from each block using TRIzol (Life Technologies Co.), and then purified using an RNeasy Plus Micro Kit (Qiagen). Plasma samples were stored at $-20^{\circ} \mathrm{C}$ until analyzed. The samples of total RNA were stored at $-80^{\circ} \mathrm{C}$ until analyzed by PCR array and real-time RT-PCR.

\section{Experiment 2: changes in daily food intake and plasma leptin level during lactation}

Daily food intakes and body weights of dams were measured at $1000 \mathrm{~h}$ until day 26 (day 5 after weaning). After measurement of food intake and body weight, blood samples were collected from dams daily in heparinized capillary tubes by the tail tip incision method. Blood samples were centrifuged at $4{ }^{\circ} \mathrm{C}$, and plasma samples were stored at $-20^{\circ} \mathrm{C}$ until analysis of plasma leptin levels.

\section{Experiment 3: changes in mRNA expression for appetite-regulating peptides in the ARC at all stages of pregnancy and lactation, and after weaning}

Body weights and 24-h food intakes were determined daily at $1000 \mathrm{~h}$ for pregnant and lactating dams, and also day 9 after weaning; those for non-lactating rats were also measured. ARC samples were immediately obtained from the brain by punch-out, which takes a target part from the brain slice. Total RNA was extracted from each ARC sample using TRIzol (Life Technologies Co.), and purified using an RNeasy Plus Micro Kit (Qiagen). The samples of total RNA were stored at $-80^{\circ} \mathrm{C}$ until analyzed by real-time RT-PCR. The diagram of each experiment timeline was shown in Supplementary Figure 1 , see section on supplementary data given at the end of this article.

\section{PCR array analysis}

Total RNA ( $1 \mu \mathrm{g}$ in a final volume of $111 \mu \mathrm{l})$ was reversetranscribed into first-strand cDNA using a RT ${ }^{2}$ First-Strand Kit (Qiagen). PCR array was carried out using a Rat Obesity $\mathrm{RT}^{2}$ Profiler PCR Array (Qiagen).

\section{Real-time RT-PCR analysis}

Real-time RT-PCR was used to quantify changes in the expression of eight genes that were chosen based on the results of PCR array analysis (Table 1). These genes, except for Npy gene, fulfill the following three criteria: i) genes of peptides excluding receptors, ii) ANOVA indicated significant differences in mRNA expression levels between groups, and iii) lactation changed mRNA expression levels by $25 \%$ or more.

Total RNA ( $2 \mu \mathrm{g}$ in a final volume of $10 \mu \mathrm{l})$ was reversetranscribed into first-strand cDNA using a High Capacity cDNA RT Kit (Applied Biosystems). Real-time quantitative PCR was carried out using TaqMan Universal Master Mix II (Applied Biosystems) with primers to amplify Npy, Agrp, galanin, hypocretin, Pomc, C3, Cck, Pyy, and lactate dehydrogenase A (Ldha). For these nine genes, probe/ primer kits were purchased from Applied Biosystems (TaqMan Gene Expression Assay ID: Rn00561681_m1, GenBank NM: NM_012614 for Npy, Assay ID: Rn01431703_g1, GenBank NM: NM_033650 for AgRP, Assay ID: Rn0583681_m1, GenBank NM: NM_033237 for Galanin, Assay ID: Rn00565995_m1, GenBank NM: NM_013179 for hypocretin, Assay ID: Rn00595020_m1, GenBank NM: NM_139326 for POMC, Assay ID: Rn0566466_m1, GenBank NM: NM_016994 for C3, Assay ID: Rn0563215_m1, GenBank NM: NM_012829 for CCK, Assay ID: Rn01460420_g1, GenBank NM: NM_001034080 for PYY, and Assay ID: Rn00820751_g1, GenBank NM: NM_017025 for Ldha).

\section{Biochemical analysis of plasma glucose, triglyceride, and total cholesterol}

Plasma glucose, triglyceride (TG), and total cholesterol were determined using a FUJIFILM DRI-CHEM3500V (Fuji Film Co., Tokyo, Japan).

\section{Analysis of plasma leptin, acyl-ghrelin, prolactin,} Pyy, Cck, and Gh

Plasma leptin, acyl-ghrelin, prolactin, $P y y, C c k$, and $G h$ were determined using a rat leptin ELISA Kit (Morinaga Institute

Published by Bioscientifica Ltd 
Table 1 Relative changes in mRNAs for 84 kinds of hypothalamic appetite-regulating substances in non-lactating rats, and on days 5 and 15 of lactation, determined by PCR array. The mRNA level in non-lactating rats was assigned a value of 1. Values are the means and the S.E.M. $(n=4)$

\section{Gene names}

Adenylate cyclase activating polypeptide 1

Adenylate cyclase activating polypeptide 1 receptor 1

Adiponectin, C1Q and collagen domain containing

Adiponectin receptor 1

Adiponectin receptor 2

Adrenergic $\alpha$-2B receptor

Adrenergic $\beta-1$ receptor

Agouti-related protein homolog

Apolipoprotein A-IV

Attractin

Brain-derived neurotrophic factor

Bombesin-like receptor 3

Complement component 3

Calcitonin-related polypeptide $\alpha$

Calcitonin receptor

CART prepropeptide

Cholecystokinin

Cholecystokinin A receptor

Colipase, pancreatic

Cannabinoid receptor 1

Ciliary neurotrophic factor

Ciliary neurotrophic factor receptor

Corticotropin-releasing hormone

Corticotropin-releasing hormone receptor 1

Dopamine receptor D1A

Dopamine receptor D2

Galanin prepropeptide

Galanin receptor 1

Glucagon

Glucagon receptor

Growth hormone 1 (GH1)

GH receptor

Ghrelin/obestatin prepropeptide

$\mathrm{GH}$ secretagogue receptor

Glucagon-like peptide 1 receptor

Prolactin-releasing hormone receptor

Melanin-concentrating hormone receptor 1

Gastrin-releasing peptide

Gastrin-releasing peptide receptor

Hypocretin

Hypocretin receptor 1

Histamine receptor $\mathrm{H} 1$

5-Hydroxytryptamine receptor $2 \mathrm{C}$

Islet amyloid polypeptide

Interleukin $1 \alpha$

Interleukin $1 \beta$

Interleukin 1 receptor, type 1

Interleukin 6

Interleukin 6 receptor

Insulin 1

Insulin 2

Insulin receptor

Leptin

Leptin receptor

Melanocortin 3 receptor

Neuromedin B

Neuromedin B receptor

\begin{tabular}{|c|c|c|}
\hline \multicolumn{2}{|c|}{ Fold change per non-lactation } & \multirow[b]{2}{*}{ ANOVA ( $P$ value) } \\
\hline Day 5 of lactation & Day 15 of lactation & \\
\hline $1.06 \pm 0.04$ & $1.05 \pm 0.09$ & - \\
\hline $0.56 \pm 0.03$ & $0.51 \pm 0.01$ & $t$ \\
\hline $2.13 \pm 1.08$ & $0.47 \pm 0.05$ & - \\
\hline $0.91 \pm 0.02$ & $0.95 \pm 0.03$ & - \\
\hline $0.89 \pm 0.08$ & $1.09 \pm 0.05$ & - \\
\hline $0.92 \pm 0.15$ & $0.97 \pm 0.10$ & - \\
\hline $0.69 \pm 0.03$ & $0.61 \pm 0.07$ & $t$ \\
\hline $1.74 \pm 0.14$ & $2.13 \pm 0.27$ & $t$ \\
\hline $0.42 \pm 0.21$ & $0.44 \pm 0.26$ & - \\
\hline $0.84 \pm 0.04$ & $0.85 \pm 0.04$ & * \\
\hline $1.08 \pm 0.04$ & $1.20 \pm 0.08$ & - \\
\hline $0.98 \pm 0.12$ & $1.29 \pm 0.20$ & - \\
\hline $0.51 \pm 0.11$ & $0.52 \pm 0.05$ & * \\
\hline $1.01 \pm 0.23$ & $0.93 \pm 0.19$ & - \\
\hline $0.97 \pm 0.06$ & $0.93 \pm 0.05$ & - \\
\hline $0.78 \pm 0.05$ & $0.85 \pm 0.07$ & * \\
\hline $0.74 \pm 0.02$ & $0.71 \pm 0.03$ & * \\
\hline $0.94 \pm 0.03$ & $1.08 \pm 0.21$ & - \\
\hline $1.17 \pm 0.11$ & $1.17 \pm 0.27$ & - \\
\hline $0.83 \pm 0.05$ & $0.92 \pm 0.03$ & - \\
\hline $0.81 \pm 0.03$ & $0.89 \pm 0.09$ & - \\
\hline $0.70 \pm 0.03$ & $0.87 \pm 0.06$ & * \\
\hline $1.00 \pm 0.08$ & $0.85 \pm 0.11$ & - \\
\hline $0.80 \pm 0.03$ & $0.95 \pm 0.09$ & - \\
\hline $0.68 \pm 0.06$ & $0.78 \pm 0.05$ & $\dagger$ \\
\hline $0.83 \pm 0.06$ & $0.97 \pm 0.08$ & - \\
\hline $0.74 \pm 0.03$ & $0.71 \pm 0.08$ & * \\
\hline $0.90 \pm 0.04$ & $0.76 \pm 0.04$ & $\dagger$ \\
\hline $1.30 \pm 0.30$ & $1.35 \pm 0.85$ & - \\
\hline $1.30 \pm 0.88$ & $3.20 \pm 0.79$ & - \\
\hline $1.72 \pm 0.62$ & $2.03 \pm 0.46$ & - \\
\hline $0.91 \pm 0.01$ & $0.98 \pm 0.01$ & * \\
\hline $0.88 \pm 0.03$ & $1.10 \pm 0.04$ & $\dagger$ \\
\hline $0.84 \pm 0.01$ & $0.95 \pm 0.11$ & - \\
\hline $1.15 \pm 0.05$ & $1.30 \pm 0.13$ & - \\
\hline $1.09 \pm 0.08$ & $1.06 \pm 0.09$ & - \\
\hline $0.98 \pm 0.07$ & $0.99 \pm 0.04$ & - \\
\hline $0.93 \pm 0.06$ & $1.08 \pm 0.11$ & - \\
\hline $0.87 \pm 0.13$ & $0.86 \pm 0.15$ & - \\
\hline $0.63 \pm 0.05$ & $0.64 \pm 0.07$ & $\dagger$ \\
\hline $0.72 \pm 0.05$ & $0.73 \pm 0.05$ & $\dagger$ \\
\hline $0.87 \pm 0.11$ & $0.89 \pm 0.02$ & - \\
\hline $1.07 \pm 0.12$ & $1.11 \pm 0.07$ & - \\
\hline $3.35 \pm 1.05$ & $2.88 \pm 1.86$ & - \\
\hline $0.79 \pm 0.20$ & $0.94 \pm 0.24$ & - \\
\hline $0.74 \pm 0.19$ & $0.53 \pm 0.06$ & - \\
\hline $0.65 \pm 0.06$ & $0.78 \pm 0.13$ & - \\
\hline $1.18 \pm 0.16$ & $1.27 \pm 0.47$ & - \\
\hline $0.69 \pm 0.08$ & $0.80 \pm 0.16$ & - \\
\hline $1.73 \pm 0.28$ & $0.98 \pm 0.32$ & - \\
\hline $0.99 \pm 0.25$ & $0.61 \pm 0.19$ & - \\
\hline $0.78 \pm 0.03$ & $0.86 \pm 0.06$ & * \\
\hline $1.28 \pm 0.74$ & $1.35 \pm 0.57$ & - \\
\hline $0.90 \pm 0.04$ & $1.20 \pm 0.15$ & - \\
\hline $0.87 \pm 0.07$ & $0.93 \pm 0.11$ & - \\
\hline $0.88 \pm 0.09$ & $1.06 \pm 0.10$ & - \\
\hline $0.94 \pm 0.07$ & $1.00 \pm 0.14$ & - \\
\hline
\end{tabular}

http://jme.endocrinology-journals.org DOI: 10.1530/JME-13-0015
(๑) 2014 The authors Printed in Great Britain
Published by Bioscientifica Ltd 


\begin{tabular}{l} 
Gene names \\
\hline Neuromedin U \\
Neuromedin U receptor 1 \\
Neuropeptide Y \\
Neuropeptide Y receptor Y1 \\
Nuclear receptor subfamily 3, group C, member 1 \\
Neurotrophic tyrosine kinase, receptor, type 1 \\
Neurotensin \\
Neurotensin receptor 1 \\
Opioid receptor, 1 \\
Opioid receptor, $\mu 1$ \\
Sigma non-opioid intracellular receptor 1 \\
Proopiomelanocortin \\
Peroxisome proliferator-activated receptor $\alpha$ \\
Peroxisome proliferator-activated receptor $\gamma$ \\
Peroxisome proliferator-activated receptor $\gamma$, coactivator $1 \alpha$ \\
Protein tyrosine phosphatase, non-receptor type 1 \\
Peptide YY \\
Receptor (G protein-coupled) activity modifying protein 3 \\
Sortilin 1 \\
Somatostatin \\
Somatostatin receptor 1 \\
Thyroid hormone receptor $\beta$ \\
Tumor necrosis factor \\
Thyrotropin-releasing hormone \\
Thyrotropin-releasing hormone receptor \\
Urocortin \\
Uncoupling protein 1 \\
\hline
\end{tabular}

${ }^{*} P<0.05$ (ANOVA) and ${ }^{\dagger} P<0.01$ (ANOVA).

of Biological Science, Inc., Kanagawa, Japan), an acyl-ghrelin ELISA Kit (Mitsubishi Chemical Medience Co., Tokyo, Japan), a rat prolactin EIA Kit (SPI-BIO, Montigny Le Bretonneux, France), a mouse/rat PYY EIA Kit (Yanaihara Institute, Inc., Shizuoka, Japan), a CCK (26-33) EIA Kit (Phoenix Pharmaceuticals, Inc., Burlingame, CA, USA), and a rat/mouse GH ELISA Kit (EMD Millipore Co., Billerica, MA, USA) following each of the manufacturer's protocols.

\section{Statistical analysis}

All data were expressed as the mean \pm s.E.M. In Experiment 1 , differences between groups were analyzed by oneway ANOVA, post hoc Fisher's test, or Tukey's test. In Experiment 2, chronological changes in body weight, food intake, and plasma leptin level during lactation were analyzed by one-way repeated ANOVA. Differences in data before and after weaning were analyzed by Dunnett's test. In the before weaning group, data for body weight and plasma leptin level before weaning were taken on day 21 of lactation, and data for food intake were taken on day 16 of lactation. The correlations between food intake and leptin level were analyzed by Pearson's correlation.
Fold change per non-lactation

\begin{tabular}{|c|c|c|}
\hline Day 5 of lactation & Day 15 of lactation & ANOVA ( $P$ value) \\
\hline $1.12 \pm 0.39$ & $0.60 \pm 0.27$ & - \\
\hline $0.72 \pm 0.11$ & $1.05 \pm 0.21$ & - \\
\hline $1.00 \pm 0.04$ & $1.06 \pm 0.09$ & - \\
\hline $0.89 \pm 0.07$ & $0.91 \pm 0.06$ & - \\
\hline $0.75 \pm 0.05$ & $0.90 \pm 0.04$ & $\dagger$ \\
\hline $0.39 \pm 0.08$ & $0.30 \pm 0.03$ & $\dagger$ \\
\hline $1.13 \pm 0.12$ & $1.00 \pm 0.17$ & - \\
\hline $0.91 \pm 0.10$ & $0.98 \pm 0.09$ & - \\
\hline $0.88 \pm 0.06$ & $1.04 \pm 0.04$ & - \\
\hline $1.00 \pm 0.06$ & $0.97 \pm 0.04$ & - \\
\hline $0.96 \pm 0.06$ & $1.00 \pm 0.02$ & - \\
\hline $0.47 \pm 0.04$ & $0.34 \pm 0.05$ & $\dagger$ \\
\hline $0.82 \pm 0.03$ & $0.99 \pm 0.09$ & - \\
\hline $0.93 \pm 0.25$ & $0.83 \pm 0.06$ & - \\
\hline $0.84 \pm 0.03$ & $0.98 \pm 0.02$ & - \\
\hline $0.76 \pm 0.02$ & $0.82 \pm 0.09$ & - \\
\hline $2.15 \pm 0.22$ & $2.37 \pm 0.49$ & * \\
\hline $0.90 \pm 0.05$ & $0.90 \pm 0.10$ & - \\
\hline $0.87 \pm 0.03$ & $1.01 \pm 0.09$ & - \\
\hline $0.87 \pm 0.09$ & $0.85 \pm 0.01$ & - \\
\hline $0.82 \pm 0.08$ & $0.77 \pm 0.08$ & - \\
\hline $0.89 \pm 0.04$ & $0.90 \pm 0.07$ & - \\
\hline $1.06 \pm 1.06$ & $1.01 \pm 0.21$ & - \\
\hline $0.94 \pm 0.94$ & $0.89 \pm 0.04$ & - \\
\hline $0.97 \pm 0.97$ & $0.97 \pm 0.08$ & - \\
\hline $1.12 \pm 1.12$ & $1.21 \pm 0.41$ & - \\
\hline $1.33 \pm 1.33$ & $1.50 \pm 0.25$ & - \\
\hline
\end{tabular}

In Experiment 3, differences between non-lactating and other groups were analyzed by Dunnett's test, and changes between time points during lactation (days 5 and 15) were analyzed by $t$-test.

\section{Results}

\section{Experiment 1}

Body weight on days 5 and 15 of lactation was significantly $(P<0.05)$ higher than in non-lactating female rats (Fig. 1A). Figure 1B shows the abdominal WAT weight in lactating (days 5 and 15) and non-lactating female rats. There were no significant differences in abdominal WAT weights between non-lactating rats and either of the lactation groups. Food intake on days 5 and 15 of lactation was significantly $(P<0.01)$ higher than in non-lactating female rats (Fig. 1C). Food intake and abdominal WAT weight on day 15 of lactation were significantly $(P<0.01)$ different than that on day 5 . Table 1 shows the relative changes in mRNA expression for 84 kinds of hypothalamic appetite-regulating substances in non-lactating rats, and on days 5 and 15 of lactation by

Published by Bioscientifica Ltd 

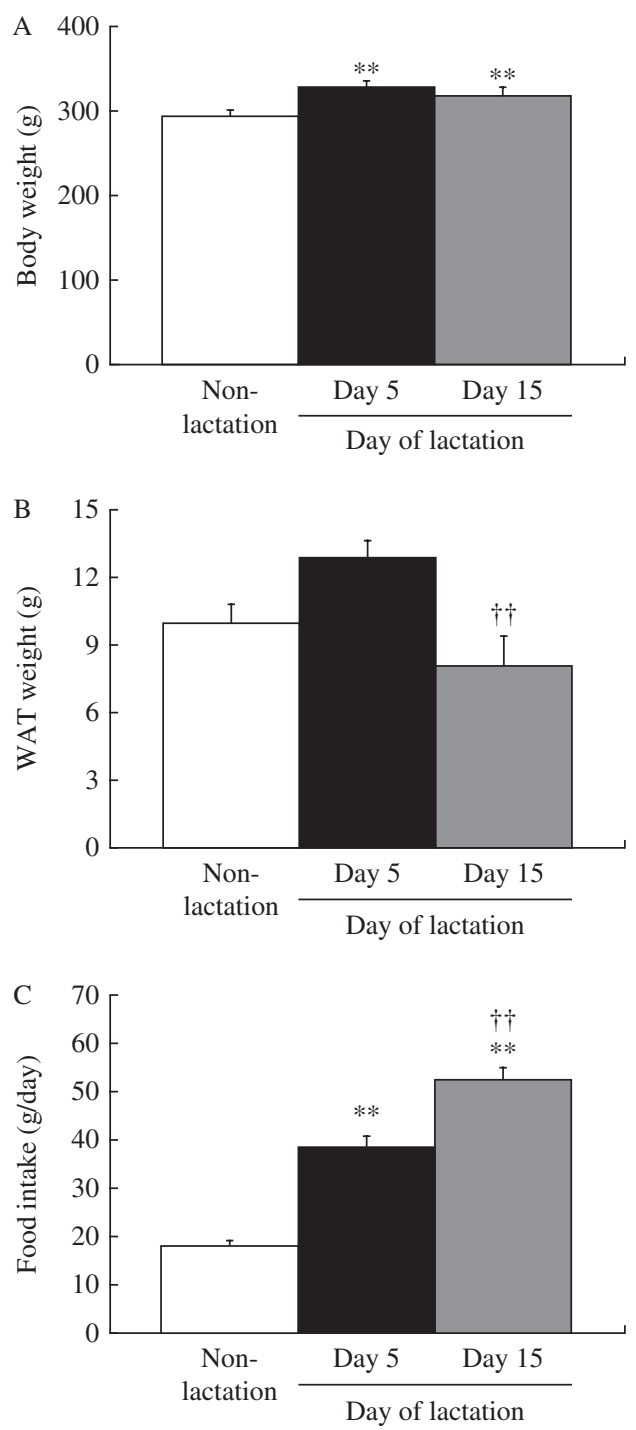

Figure 1

(A) Body weight, (B) WAT weight, and (C) food intake during $24 \mathrm{~h}$ in non-lactating rats (clear bars), and on day 5 (solid bars) and day 15 (gray bars) of lactation. Values are the means and vertical lines represent the S.E.M. $(n=6) .{ }^{*} P<0.05$ vs non-lactation, $* * P<0.01$ vs non-lactation, and ${ }^{+\dagger} P<0.01$ vs day 5 of lactation.

PCR array. During lactation, hypothalamic mRNA expression was significantly $(P<0.05$ and $P<0.01)$ different from that in non-lactating female rats for the following: adenylate cyclase-activating polypeptide 1 receptor 1, adrenergic $\beta-1$ receptor, Agrp, attractin, C3, CART prepropeptide (Cartpt), Cck, ciliary neurotrophic factor receptor, dopamine receptor D1A (Drd1a), galanin prepropeptide, galanin receptor 1 , GH receptor, ghrelin, hypocretin, hypocretin receptor type 1 , insulin receptor, nuclear receptor subfamily 3 group $C$ member 1 , neurotrophic tyrosine kinase receptor type 1, Pomc, and Pyy.
Figure 2 shows the relative mRNA expression for hypothalamic appetite-regulating neuropeptides in lactating (days 5 and 15) and non-lactating female rats. There were no significant differences in the mRNA expression for hypothalamic Npy, Cck, and hypocretin between nonlactating rats and both lactation groups. The hypothalamic Agrp and Pyy mRNA expression was significantly $(P<0.05$ and $P<0.01)$ increased in both of the lactation groups relative to the non-lactation group. Lactating rats showed significantly $(P<0.05)$ higher hypothalamic Agrp mRNA expression on day 15 than on day 5 , but there was no significant difference in Pyy mRNA expression between days 5 and 15 . Both lactation groups showed significantly $(P<0.05$ and $P<0.01)$ lower hypothalamic Pomc, $C 3$, and galanin mRNA expression than non-lactating rats. Figure 3 shows the plasma components in non-lactating rats, and on days 5 and 15 of lactation. On both days 5 and 15 of lactation, plasma glucose and TG levels were significantly $(P<0.01)$ lower than in non-lactating rats (Fig. 3A and B). There were no significant differences in the levels of plasma total cholesterol, GH, and acyl-ghrelin between non-lactating rats and both lactation groups (Fig. 3C, D and F). The plasma leptin level was significantly $(P<0.01)$ lower in each of the lactation groups than in non-lactating rats (Fig. 3E), but in lactating rats it was significantly lower $(P<0.01)$ on day 15 than that on day 5. The plasma prolactin level was significantly $(P<0.01)$ higher on day 5 of lactation than in non-lactating rats (Fig. 3G). The plasma PYY level was significantly $(P<0.05$ and $P<0.01)$ higher on days 5 and 15 of lactation than in non-lactating rats (Fig. 3H). The plasma CCK level was significantly

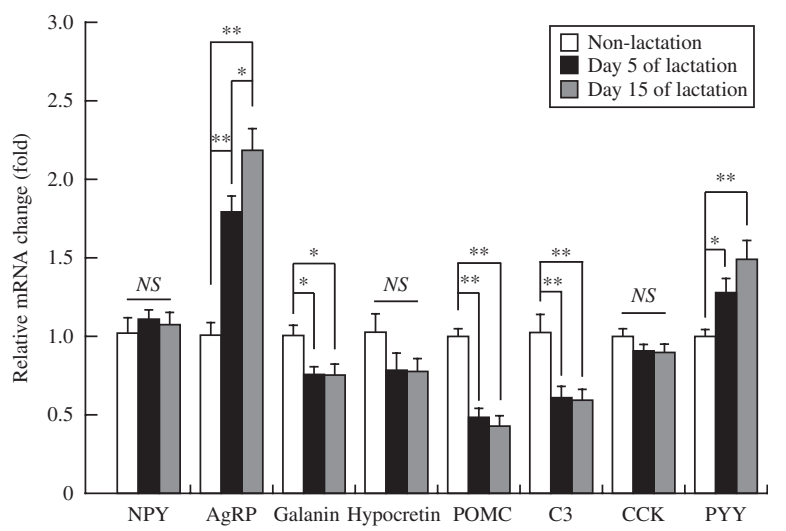

Figure 2

Relative changes in mRNAs for various hypothalamic appetite-regulating neuropeptides in non-lactating rats (clear bars), and on day 5 (solid bars) and day 15 (gray bars) of lactation. The mRNA level in non-lactating rats was assigned a value of 1 . Values are the means and vertical lines represent the S.E.M. $(n=6)$. ${ }^{*} P<0.05$ and $* * P<0.01$.

Published by Bioscientifica Ltd 

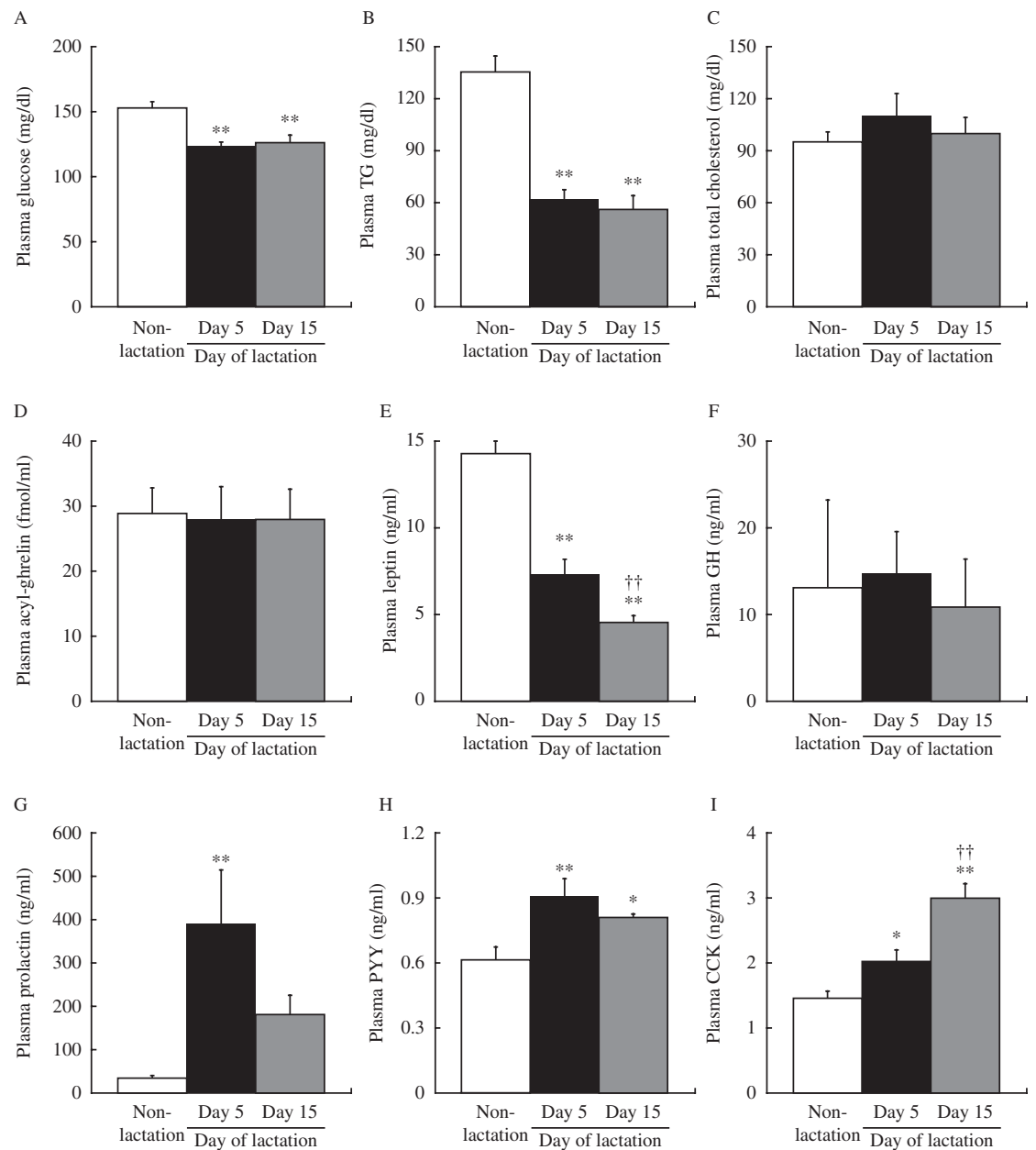

Figure 3

(A) Plasma glucose, (B) plasma triglyceride, (C) plasma total cholesterol, (D) plasma acyl-ghrelin, (E) plasma leptin, (F) plasma growth hormone, (G) plasma prolactin, (H) plasma PYY, and (I) plasma CCK levels in non-lactating rats (clear bars), and on day 5 (solid bars) and day 15

$(P<0.05$ and $P<0.01)$ higher in each of the lactation groups (days 5 and 15) than in non-lactating rats, but in lactating rats that on day 15 was significantly $(P<0.05)$ higher than on day 5 (Fig. 3I).

\section{Experiment 2}

Figure 4 shows the chronological changes in body weight, food intake, and plasma leptin level in female rats during lactation and after weaning, and the correlations of food intake with the plasma leptin level during days 1-16 of lactation for individual rats. Body weights changed significantly $(P<0.001)$ during lactation. In comparison with body weight on day 21 of lactation, there was a significant $(P<0.01)$ change on days 22, 24, and 25 (days 1,3 , and 4 after weaning) (Fig. 4A). Food intake was significantly (gray bars) of lactation. Values are the means and vertical lines represent the S.E.M. (A, B, C, D, E and G, $n=6$; F: non-lactation: $n=4$, days 5 and 15 of lactation: $n=6)$. ${ }^{* *} P<0.01$ vs non-lactation and ${ }^{\dagger \dagger} P<0.01$ vs day 5 of lactation.

$(P<0.001)$ increased during the lactation period. Food intake after weaning was significantly $(P<0.01)$ lower than on day 16 of lactation (Fig. 4B). Plasma leptin levels were significantly $(P<0.001)$ decreased during lactation, but after weaning they were significantly $(P<0.01)$ higher than on day 21 of lactation (Fig. 4C). During lactation (days 1-16), the plasma leptin level was negatively correlated with food intake in individual rats $(r=-0.672$ to $-0.866, P<0.01$; Fig. 4D, E, F and G).

\section{Experiment 3}

Body weight and food intake during pregnancy, and on days 5 and 15 of lactation were significantly $(P<0.01)$ higher than in non-lactating female rats (Fig. $5 \mathrm{~A}$ and $\mathrm{B}$ ). Food intake on after weaning was significantly $(P<0.01)$

Published by Bioscientifica Ltd 

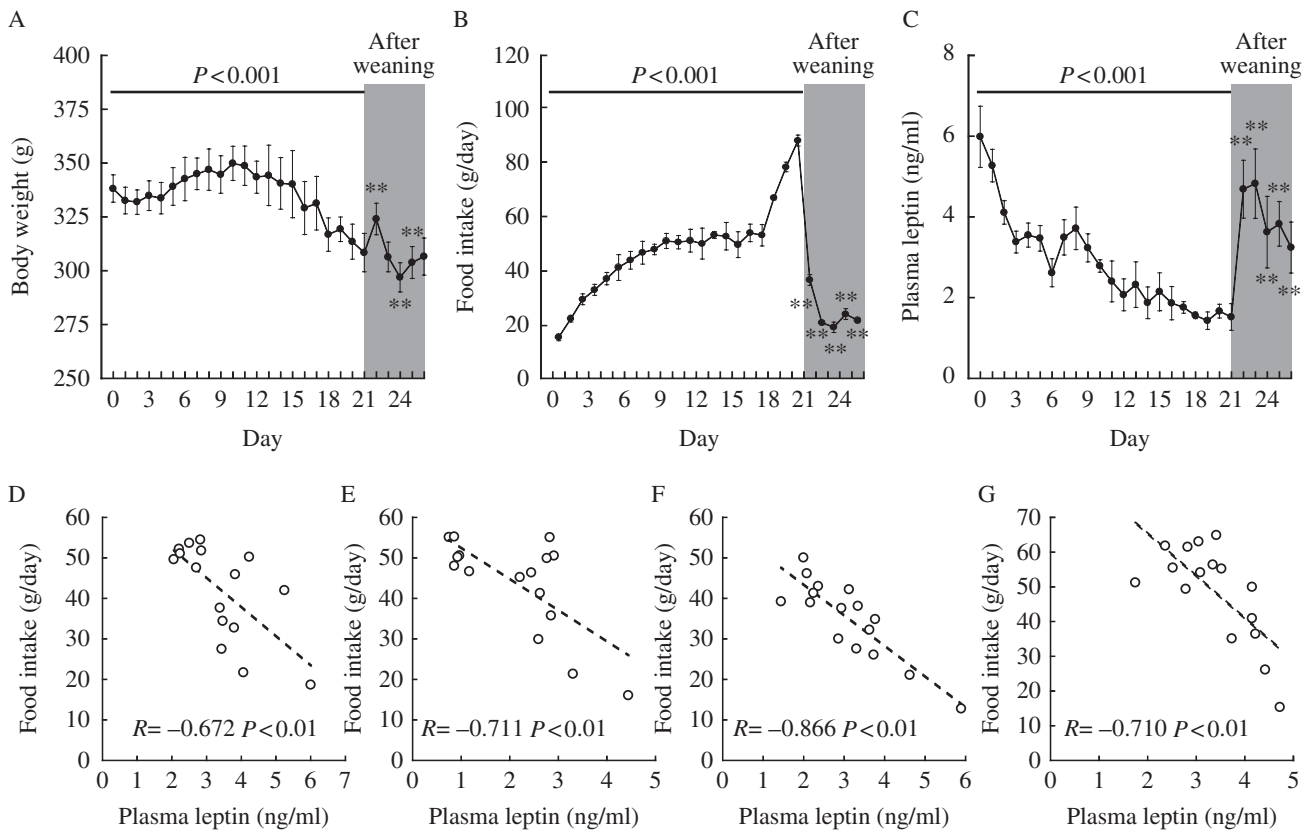

\section{Figure 4}

(A) Daily body weight, (B) daily food intake during $24 \mathrm{~h}$, and (C) daily plasma leptin levels during lactation (days $0-21$ ) and after weaning (days 22-26). Values are the means and vertical lines represent the S.E.M. $(n=4)$ Correlations of food intake with the plasma leptin level during lactation

higher than in non-lactating female rats. Food intake on day 15 of lactation was significantly $(P<0.01)$ different from that on day 5. Figure 6 shows the relative mRNA expression for ARC appetite-regulating neuropeptides at all stages of pregnancy, lactation (days 5 and 15), and after weaning, and in non-lactating female rats. During pregnancy and lactation (days 5 and 15), Agrp and Pyy mRNA expression was significantly $(P<0.05$ and $P<0.01)$ higher than in non-lactating rats. On day 15 of lactation, rats showed significantly $(P<0.01)$ higher $N p y$ mRNA expression than non-lactating rats. Both lactation groups (days 5 and 15) showed significantly $(P<0.01)$ lower Pomc and $C c k$ mRNA expression than non-lactating rats. There were no significant differences in the mRNA expression for C3, galanin and hypocretin between non-lactating rats and other groups. Lactating rats showed significantly $(P<0.05)$ higher Agrp and Npy mRNA expression on day 15 than on day 5 , but there was no significant difference in the Pyy mRNA expression between days 5 and 15 .

\section{Discussion}

In order to clarify the mechanism responsible for induction of hyperphagia on lactation in female rats, we analyzed the daily food intake, plasma leptin levels, and (days 1-16) in individual dams (D, E, F and G, each 16 points). $P<0.001$ (ANOVA) during lactation. (A and $C$ ) $* * P<0.01$ vs day 21 of lactation. (B) $* * P<0.01$ vs day 16 of lactation

mRNA expression of appetite-regulating peptides in ARC. Results demonstrating mRNA expression levels of appetite-regulating peptides in ARC of lactating rats suggested that Agrp, Npy (only on day 15 of lactation), and Pyy were upregulated, whereas Pomc, Cck were downregulated, in comparison with non-lactating rats. Food consumption was two to three times higher in lactating rats, and increased with the course of lactation. Crowley et al. (2003) reported that chronic administration of an NPY antagonist into the third ventricle had a less marked effect on feeding in lactating rats than in non-lactating rats. This suggested that the continued hyperphagia accompanying the course of lactation might be closely associated with increased hypothalamic Agrp mRNA expression. On the other hand, it has been reported that lactating rats show significantly lower mRNA expression for the hypothalamic anorexigenic peptide POMC than non-lactating rats (Smith 1993, Mann et al. 1997). The activity of POMC neurons is inhibited by the activity of AgRP neurons (Cone 2005, Tong et al. 2008). Furthermore, a population of neurons in ARC is in direct contact with the circulation and shows higher sensitivity to circulating leptin than neurons behind the BBB in the hypothalamus (Faouzi et al. 2007). This study showed that the plasma leptin level decreased continually during the continued

Published by Bioscientifica Ltd 

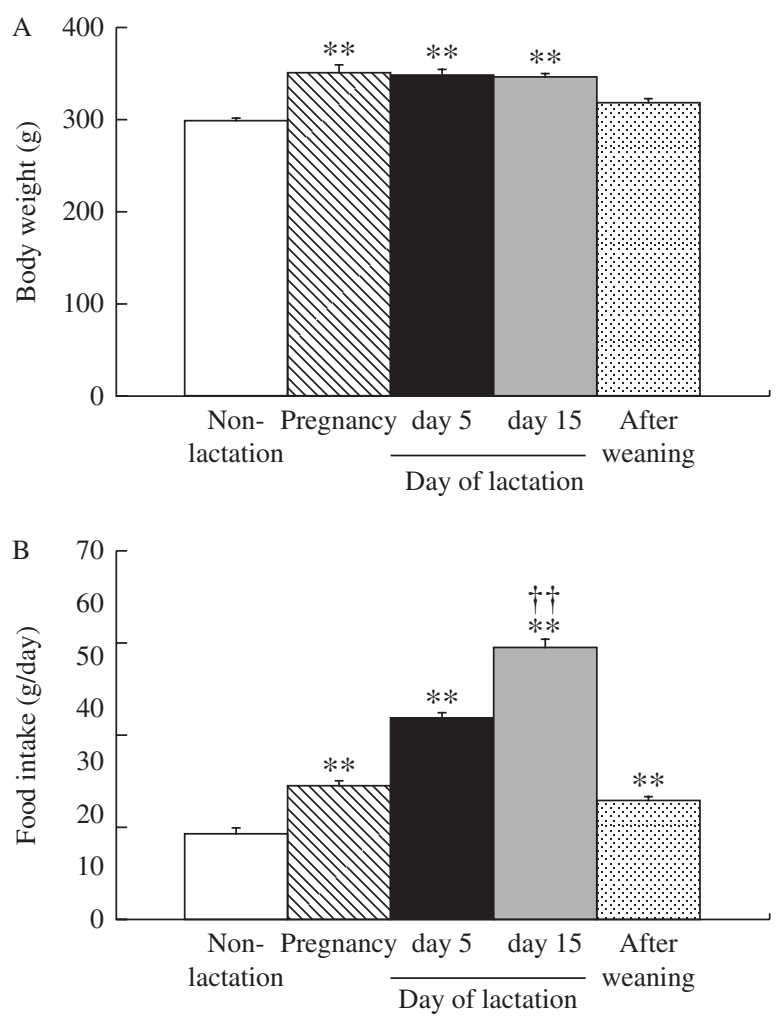

Figure 5

(A) Body weight and (B) food intake during $24 \mathrm{~h}$ in non-lactating rats (clear bars), and on day 14 of pregnancy (diagonal bars), day 5 (solid bars) and day 15 (gray bars) of lactation, and day 9 after weaning (dot bars). Values are the means and vertical lines represent the S.E.M. $(n=6) . * * P<0.01$ vs non-lactation, and ${ }^{\dagger+} P<0.01$ vs day 5 of lactation.

hyperphagia accompanying the course of lactation. In this study, the increased Agrp mRNA expression in ARC may have contributed to the decreased Pomc mRNA expression in ARC and circulating leptin levels during lactation.

Food consumption was significantly higher on days 5 and 15 of lactation than in non-lactating rats. PYY, a member of the NPY peptide family secreted primarily from endocrine L cells, binds to the Y2 NPY receptor and inhibits the activation of NPY/AgRP neurons (Moran 2006, Schwartz 2006). In addition, both hypothalamic immunoreactivity and Pyy mRNA expression have been observed in rat and human (Ekman et al. 1986, Morimoto et al. 2008). Batterham et al. (2002) reported that food intake in male rats was reduced after injection of PYY into ARC. However, our present results suggested that mRNA expression for anorexigenic PYY in ARC was higher in pregnant and lactating rats than in non-lactating rats. Aguilar et al. (2004) reported that i.c.v. administration of PYY in hyperprolactinemic female rats promoted secretion of prolactin in the anterior pituitary. Moreover, their group showed that PYY directly stimulated secretion of luteinizing hormone and follicle-stimulating hormone at the pituitary level in prepubertal female rats (FernandezFernandez et al. 2005). Therefore, in pregnant and lactating female rats, the increased Pyy mRNA expression in ARC may promote the secretion of gonadotropin and prolactin. Further studies will be required to investigate the central effects of PYY during pregnancy and lactation. Hypocretin, an orexigenic hormone, binds to the orexin1 and orexin2 receptors and activates NPY neurons (Sakurai et al. 1998, Dube et al. 1999, Yamanaka et al. 2000). There was no difference in the mRNA expression for orexigenic hypocretin in ARC between non-lactating rats and both pregnant and lactating rats, and also post-weaning rats. Hypocretin may thus not play a role in the stimulation of food intake during lactation, as has been reported previously (Brogan et al. 2000, Sun et al. 2003). CCK, an anorexigenic molecule secreted primarily from intestinal I-cells, binds to the CCK1 receptor and activates POMC neurons in the NTS via the vagus nerve (Fan et al. 2004, Millington 2007). In addition, hypothalamic CCK mRNA expression has been observed in rats and humans (Iadarola et al. 1989, Ding \& Bayer 1993). During lactation, although CCK mRNA expression in ARC was lower than that in nonlactating female rats, the level of $C C K$ in plasma was increased. Chen et al. (2008) reported that administration of CCK in the dorsomedial hypothalamus (DMH) decreased food intake and the level of NPY mRNA in $\mathrm{DMH}$, and increased the number of c-Fos positive cells in ARC. In addition, their results suggested that peripheral administration of CCK did not increase the number of c-Fos positive cells in ARC. Therefore, lower expression of

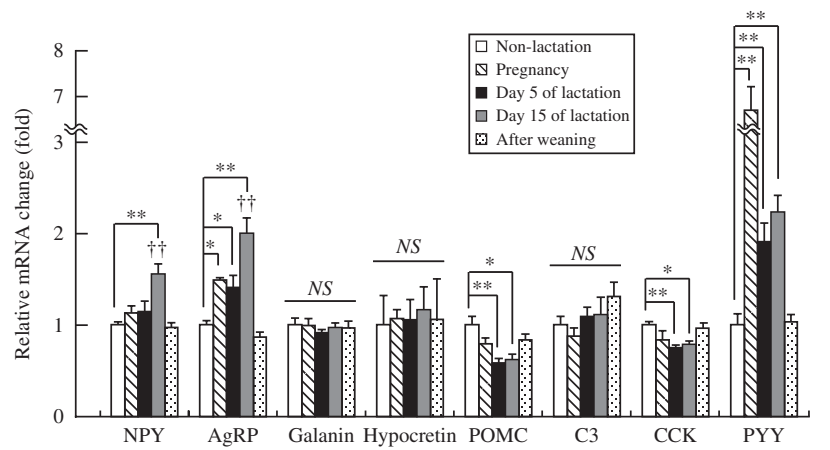

Figure 6

Relative changes in mRNAs for various arcuate nucleus appetite-regulating neuropeptides in non-lactating rats (clear bars), and on day 14 of pregnancy (diagonal bars), day 5 (solid bars) and day 15 (gray bars) of lactation, and day 9 after weaning (dot bars). The mRNA level in non-lactating rats was assigned a value of 1 . Values are the means and vertical lines represent the S.E.M. $(n=6) .{ }^{+\dagger} P<0.01$ vs day 5 of lactation, $* P<0.05$, and $* * P<0.01$

Published by Bioscientifica Ltd http://jme.endocrinology-journals.org DOI: 10.1530/JME-13-0015 (c) 2014 The authors Printed in Great Britain 
CCK mRNA in ARC may be involved in the long-term hyperphagia characteristic of lactation.

In this study, the hypothalamic C3 mRNA expression in lactating rats was lower than that in non-lactating rats. However, there were no differences in C3 mRNA expression in ARC between non-lactating rats and other groups. C3, a complement protein, binds to the C3a receptor $(\mathrm{C} 3 \mathrm{aR})$ after it has been cleaved to $\mathrm{C} 3 \mathrm{a}$ and $\mathrm{C} 3 \mathrm{~b}$. C3 is cleaved to C3a and C3b by C3 convertase (Koch et al. 2012). Therefore it is suggested that the level of $\mathrm{C} 3 \mathrm{a}$ in the brain of lactating rats is lower than in non-lactating rats. Ohinata et al. (2002) reported that, in male mice, intraventricular administration of $\mathrm{C} 3 \mathrm{a}$ reduced food intake, and that C3a receptor activity suppressed food intake through production of PGE2 and EP4 receptor activity (Ohinata et al. 2007). Therefore, the decreased hypothalamic C3 mRNA expression (except for ARC) in lactating rats may be indirectly involved in the hyperphagia associated with lactation. Further research will be required to investigate the levels of $\mathrm{C} 3$ convertase and the suppressive effects of C3a on appetite during lactation.

Our results also suggested that plasma prolactin levels were increased in lactating dams. During lactation, prolactin and oxytocin play important roles in milk production and ejection. Galanin, an orexigenic hormone secreted from the gut, binds to its receptors GalR1, GalR2, and GalR3. In ARC and the paraventricular nucleus, galanin activates NPY neurons by binding to GalR1 (Fang et al. 2012). Furthermore, oxytocin and galanin neurons have been identified in the hypothalamic supraoptic nucleus (Melnikova et al. 2006, Sakamoto et al. 2008). Galanin suppresses the hypothalamic oxytocin mRNA expression (Ciosek \& Cisowska 2003). Although one of the effects of galanin is to increase food intake, we confirmed that the hypothalamic galanin mRNA expression was lower in lactating, than in non-lactating, rats as has been reported previously (Landry et al. 1997). In addition, there were no differences in galanin mRNA expression in ARC between non-lactating rats and other groups. Thus, the decreased hypothalamic galanin mRNA expression in lactating rats may not suppress release of oxytocin from the hypothalamus for milk ejection.

With regard to changes in blood components, the plasma levels of TG and glucose were decreased on days 5 and 15 of lactation, relative to those in non-lactating rats. These results are consistent with previously reported data for lactating rats (Jones et al. 1984, Martínez et al. 2002). Blood glucose and TG in lactating rats are important resources for mammary gland milk production, and their decline may reflect their depletion during milk production. It has been reported that the circulating levels of PYY and CCK increase postprandially (Coll et al. 2007, Zwirska-Korczala et al. 2007). The circulating levels of PYY and CCK in lactating rats were also higher than in nonlactating rats, as has been reported previously (Lindén et al. 1990, Taylor et al. 2009). However, Npy mRNA expression in ARC on day 15 of lactation was higher than in non-lactating female rats. Peripheral PYY and CCK signals arrive at NTS via the vagal afferent pathway (Fan et al. 2004, Koda et al. 2005, Millington 2007). Ladyman et al. (2011) reported that i.p. injection of CCK in pregnant rats did not significantly decrease food intake or increase the number of c-Fos positive cells in the hypothalamic paraventricular nucleus and supraoptic nucleus. Therefore, during lactation, peripheral PYY and CCK may be reduced sensitivity via the vagal afferent pathway.

This study showed that the plasma leptin level decreased continually during the course of lactation. In comparison with non-lactating rats, WAT weight during lactation was either unchanged (day 15) or increased (day 5). However, the plasma leptin level during lactation was lower than in non-lactating rats. In addition, on day 1 after weaning, the leptin level was suddenly increased relative to the day before weaning (day 21 of lactation). Synthesis of leptin is promoted by insulin stimulation in WAT (Barr et al. 1997). It has also been reported that prolactin is involved in insulin resistance in WAT during lactation (Graham et al. 1990) and suppresses insulininduced leptin production in WAT (Ling \& Billig 2001). In this study, plasma prolactin levels in lactating rats were significantly higher than in non-lactating rats. It has been reported that after weaning, the plasma level of prolactin declines in non-lactating female rats within a few hours (van Landehem \& van de Wiel 1978). In addition, Brogan et al. (1999) reported that initiation of milk production, but not suckling stimulus alone, participated in the decrease in the serum leptin level during lactation. Therefore, the decrease in the plasma leptin level during lactation may reflect not only the decrease of WAT weight but also the increase in the prolactin level in response to the suckling stimulus. Furthermore, cancellation of the suppression of leptin secretion by stopping milk production may be involved in the decreased food intake after weaning. Leptin suppresses the activity of NPY/AgRP neurons and increases that of POMC neurons in ARC (Schwartz et al. 2000). The daily plasma leptin level during lactation (days 1-16) was negatively correlated with food intake. In addition, our previous study demonstrated that the hyperphagia of lactating rats could be partly due to reduced sensitivity of neurons to leptin in blood

Published by Bioscientifica Ltd 
(Suzuki et al. 2010). These results suggest that increased Agrp mRNA expression and decreased Pomc mRNA in ARC expression in lactating rats contribute to a decline in both leptin secretion and sensitivity.

Acyl-ghrelin, an orexigenic hormone secreted from the stomach, binds to the GH secretagogue receptor (GHS-R) and stimulates the release of NPY in the hypothalamus (Nakazato et al. 2001, Wren et al. 2001). Although food consumption increased during the course of lactation, many studies have demonstrated no change in, or reduced, levels of acyl-ghrelin in the blood of lactating rats (Abizaid et al. 2008, Taylor et al. 2009). In this study, we confirmed that the plasma acyl-ghrelin levels also did not differ between non-lactating rats and both of the lactation groups. Abizaid et al. (2008) reported that rats on day 15 of lactation showed increased hypothalamic acylghrelin receptor (GHS-R1a) mRNA expression relative to non-lactating rats, and that the expression returned to the baseline after litter removal. In addition, milk production in lactating rats is reportedly increased by chronic administration of acyl-ghrelin (Nakahara et al. 2003). Therefore, acyl-ghrelin in lactating rats may play an important role in milk production through suckling stimulation rather than through regulation of appetite.

In conclusion, this study has clarified the synchronous changes in the levels of many appetite-regulating peptides during pregnancy, lactation, and after weaning in female rats. Our findings suggest that the hyperphagia associated with lactation is caused by decreased Pomc and Cck and increased Agrp mRNA expression in ARC. A noteworthy finding was that Agrp mRNA expression in ARC was associated with a decrease in the blood leptin level during course of lactation. In lactating rats, therefore, Agrp mRNA expression in ARC and the level of leptin in blood may be involved in the continued hyperphagia accompanying the course of lactation.

\section{Supplementary data}

This is linked to the online version of the paper at http://dx.doi.org/10.1530/ JME-13-0015.

\section{Declaration of interest}

The authors declare that there is no conflict of interest that could be perceived as prejudicing the impartiality of the research reported.

\section{Funding}

This study was supported in part by grants-in-aid from the Ministry of Education, Science, Sports, and Culture, Japan ( $\mathrm{K} \mathrm{N})$, and by the Program for Promotion of Basic Research Activities for Innovative Bioscience, PROBRAIN (N M).

\section{References}

Abizaid A, Schiavo L \& Diano S 2008 Hypothalamic and pituitary expression of ghrelin receptor message is increased during lactation. Neuroscience Letters 440 206-210. (doi:10.1016/j.neulet.2008.05.105)

Aguilar E, Fernandez-Fernandez R, Tena-Sempere M \& Pinilla L 2004 Effects of peptide YY(3-36) on PRL secretion: pituitary and extra-pituitary actions in the rat. Peptides 25 1147-1152. (doi:10.1016/j.peptides.2004. 04.002)

Anand B \& Brobeck J 1951 Hypothalamic control of food intake in rats and cats. Yale Journal of Biology and Medicine 24 123-140.

Asakuma S, Hiraku O, Kurose Y, Kobayashi S \& Terashima Y 2004 Diurnal rhythm of cerebrospinal fluid and plasma leptin levels related to feeding in non-lactating and lactating rats. Journal of Endocrinology 180 283-286. (doi:10.1677/joe.0.1800283)

Barr VA, Malide D, Zarnowski MJ, Taylor SI \& Cushman SW 1997 Insulin stimulates both leptin secretion and production by rat white adipose tissue. Endocrinology 138 4463-4472. (doi:10.1210/en.138.10.4463)

Batterham RL, Cowley MA, Small CJ, Herzog H, Cohen MA, Dakin CL, Wren AM, Brynes AE, Low MJ, Ghatei MA et al. 2002 Gut hormone PYY3-36 physiologically inhibits food intake. Nature 418 650-654. (doi:10.1038/nature00887)

Brogan RS, Mitchell SE, Trayhurn P \& Smith MS 1999 Suppression of leptin during lactation: contribution of the suckling stimulus versus milk production. Endocrinology 140 2621-2627. (doi:10.1210/en.140. $6.2621)$

Brogan R, Grove K \& Smith M 2000 Differential regulation of leptin receptor but not orexin in the hypothalamus of the lactating rat. Journal of Neuroendocrinology 12 1077-1086. (doi:10.1046/j.1365-2826. 2000.00559.x)

Buyse M, Ovesjö ML, Goïot H, Guilmeau S, Péranzi G, Moizo L, Walker F, Lewin MJ, Meister B \& Bado A 2001 Expression and regulation of leptin receptor proteins in afferent and efferent neurons of the vagus nerve. European Journal of Neuroscience 14 64-72. (doi:10.1046/j.0953-816x. 2001.01628.x)

Chen J, Scott KA, Zhao Z, Moran TH \& Bi S 2008 Characterization of the feeding inhibition and neural activation produced by dorsomedial hypothalamic cholecystokinin administration. Neuroscience 152 178-188. (doi:10.1016/j.neuroscience.2007.12.004)

Chilliard Y, Delavaud C \& Bonnet M 2005 Leptin expression in ruminants: nutritional and physiological regulations in relation with energy metabolism. Domestic Animal Endocrinology 29 3-22. (doi:10.1016/ j.domaniend.2005.02.026)

Ciosek J \& Cisowska A 2003 Centrally administered galanin modifies vasopressin and oxytocin release from the hypothalamo-neurohypophysial system of euhydrated and dehydrated rats. Journal of Physiology and Pharmacology 54 625-641.

Clarke I \& Henry B 1999 Leptin and reproduction. Reviews of Reproduction 4 48-55. (doi:10.1530/ror.0.0040048)

Cohen P, Miyazaki M, Socci ND, Hagge-Greenberg A, Liedtke W, Soukas AA, Sharma R, Hudgins LC, Ntambi JM \& Friedman JM 2002 Role for stearoylCoA desaturase-1 in leptin-mediated weight loss. Science 297 240-243. (doi:10.1126/science.1071527)

Coll A, Farooqi I \& O'Rahilly S 2007 The hormonal control of food intake. Cell 129 251-262. (doi:10.1016/j.cell.2007.04.001)

Cone R 2005 Anatomy and regulation of the central melanocortin system. Nature Neuroscience 8 571-578. (doi:10.1038/nn1455)

Crowley WR, Ramoz G \& Hurst B 2003 Evidence for involvement of neuropeptide $\mathrm{Y}$ and melanocortin systems in the hyperphagia of lactation in rats. Pharmacology, Biochemistry, and Behavior 74 417-424. (doi:10.1016/S0091-3057(02)01006-7)

Published by Bioscientifica Ltd 
Crowley WR, Ramoz G, Torto R, Keefe KA, Wang JJ \& Kalra SP 2007 Neuroendocrine actions and regulation of hypothalamic neuropeptide Y during lactation. Peptides 28 447-452. (doi:10.1016/j.peptides.2006. 09.025)

Cui JG, Tang GB, Wang DH \& Speakman JR 2011 effects of leptin infusion during peak lactation on food intake, body composition, litter growth, and maternal neuroendocrine status in female Brandt's voles (Lasiopodomys brandtii). American Journal of Physiology. Regulatory, Integrative and Comparative Physiology 300 R447-R459. (doi:10.1152/ajpregu. 00121.2010)

Ding XZ \& Bayer BM 1993 Increases of CCK mRNA and peptide in different brain areas following acute and chronic administration of morphine. Brain Research 625 139-144. (doi:10.1016/0006-8993(93)90146-E)

Dube M, Kalra S \& Kalra P 1999 Food intake elicited by central administration of orexins/hypocretins: identification of hypothalamic sites of action. Brain Research 842 473-477. (doi:10.1016/S0006 8993(99)01824-7)

Ekman R, Wahlestedt C, Böttcher G, Sundler F, Håkanson R \& Panula P 1986 Peptide YY-like immunoreactivity in the central nervous system of the rat. Regulatory Peptides 16 157-168. (doi:10.1016/01670115(86)90059-5)

Ellacott K \& Cone R 2004 The central melanocortin system and the integration of short- and long-term regulators of energy homeostasis. Recent Progress in Hormone Research 59 395-408. (doi:10.1210/rp.59. 1.395)

Etherton T \& Bauman D 1998 Biology of somatotropin in growth and lactation of domestic animals. Physiological Reviews 78 745-761.

Fan W, Ellacott K, Halatchev I, Takahashi K, Yu P \& Cone R 2004 Cholecystokinin-mediated suppression of feeding involves the brainstem melanocortin system. Nature Neuroscience 7 335-336. (doi:10.1038/nn1214)

Fang P, Yu M, Guo L, Bo P, Zhang Z \& Shi M 2012 Galanin and its receptors: a novel strategy for appetite control and obesity therapy. Peptides $\mathbf{3 6}$ 331-339. (doi:10.1016/j.peptides.2012.05.016)

Faouzi M, Leshan R, Björnholm M, Hennessey T, Jones J \& Münzberg H 2007 Differential accessibility of circulating leptin to individual hypothalamic sites. Endocrinology 148 5414-5423. (doi:10.1210/en. 2007-1018)

Fernandez-Fernandez R, Aguilar E, Tena-Sempere M \& Pinilla L 2005 Effects of polypeptide $\mathrm{YY}(3-36)$ upon luteinizing hormone-releasing hormone and gonadotropin secretion in prepubertal rats: in vivo and in vitro studies. Endocrinology 146 1403-1410. (doi:10.1210/en.2004-0858)

Flint D, Tonner E, Beattie J \& Panton D 1992 Investigation of the mechanism of action of growth hormone in stimulating lactation in the rat. Journal of Endocrinology 134 377-383. (doi:10.1677/joe.0. 1340377)

Graham M, Finley E \& Vernon R 1990 Factors controlling insulin resistance in white adipose tissue of lactating rats. Biochemical Society Transactions 18 492-493.

Hetherington AW \& Ranson SW 1940 Hypothalamic lesions and adiposity in the rat. Anatomical Record 78 149-172. (doi:10.1002/ar.1090780203)

Higuchi T, Honda K, Fukuoka T, Negoro H \& Wakabayashi K 1985 Release of oxytocin during suckling and parturition in the rat. Journal of Endocrinology 105 339-346. (doi:10.1677/joe.0.1050339)

Iadarola MJ, Naranjo JR, Duchemin AM \& Quach TT 1989 Expression of cholecystokinin and enkephalin mRNA in discrete brain regions. Peptides 10 687-692. (doi:10.1016/0196-9781(89)90160-5)

Jones R, Ilic V \& Williamson D 1984 Physiological significance of altered insulin metabolism in the conscious rat during lactation. Biochemical Journal 220 455-460.

Kawano H, Honma S, Honma A, Horie M, Kawano Y \& Hayashi S 2002 Melanin-concentrating hormone neuron system: the wide web that controls the feeding. Anatomical Science International 77 149-160. (doi:10.1046/j.0022-7722.2002.00027.x)

Koch T, Reuter M, Barthel D, Böhm S, van den Elsen J, Kraiczy P, Zipfel P \& Skerka C 2012 Staphylococcus aureus proteins Sbi and Efb recruit human plasmin to degrade complement C3 and C3b. PLoS ONE 7 e47638. (doi:10.1371/journal.pone.0047638)

Koda S, Date Y, Murakami N, Shimbara T, Hanada T, Toshinai K, Niijima A, Furuya M, Inomata N, Osuye K et al. 2005 The role of the vagal nerve in peripheral PYY3-36-induced feeding reduction in rats. Endocrinology 146 2369-2375. (doi:10.1210/en.2004-1266)

Ladyman SR, Sapsford TJ \& Grattan DR 2011 Loss of acute satiety response to cholecystokinin in pregnant rats. Journal of Neuroendocrinology $\mathbf{2 3}$ 1091-1098. (doi:10.1111/j.1365-2826.2011.02191.x)

Van Landehem \& Van de Wiel 1978 Radioimmunoassay for porcine prolactin: plasma levels during lactation, suckling and weaning and after TRH administration. Acta Endocrinologica 88 653-667.

Landry M, Roche D, Angelova E \& Calas A 1997 Expression of galanin in hypothalamic magnocellular neurones of lactating rats: co-existence with vasopressin and oxytocin. Journal of Endocrinology 155 467-481. (doi:10.1677/joe.0.1550467)

Lee L, Haisenleder D, Marshall J \& Smith M 1989 The role of the suckling stimulus in regulating pituitary prolactin mRNA in the rat. Molecular and Cellular Endocrinology 64 243-249. (doi:10.1016/03037207(89)90151-2)

Lee GH, Proenca R, Montez JM, Carroll KM, Darvishzadeh JG, Lee JI \& Friedman JM 1996 Abnormal splicing of the leptin receptor in diabetic mice. Nature 379 632-635. (doi:10.1038/379632a0)

Levin N, Nelson C, Gurney A, Vandlen R \& de Sauvage F 1996 Decreased food intake does not completely account for adiposity reduction after ob protein infusion. PNAS 93 1726-1730. (doi:10.1073/pnas.93. 4.1726)

Lindén A, Uvnäs-Moberg K, Forsberg G, Bednar I, Enerotht P \& Södersten P 1990 Involvement of cholecystokinin in food intake: II. Lactational hyperphagia in the rat. Journal of Neuroendocrinology 2 791-796. (doi:10.1111/j.1365-2826.1990.tb00642.x)

Ling C \& Billig H 2001 PRL receptor-mediated effects in female mouse adipocytes: PRL induces suppressors of cytokine signaling expression and suppresses insulin-induced leptin production in adipocytes in vitro. Endocrinology 142 4880-4890. (doi:10.1210/en.142.11.4880)

Mann P, Rubin B \& Bridges R 1997 Differential proopiomelanocortin gene expression in the medial basal hypothalamus of rats during pregnancy and lactation. Molecular Brain Research 46 9-16. (doi:10.1016/S0169$328 X(96) 00267-7)$

Martínez S, Barbas C \& Herrera E 2002 Uptake of alpha-tocopherol by the mammary gland but not by white adipose tissue is dependent on lipoprotein lipase activity around parturition and during lactation in the rat. Metabolism: Clinical and Experimental 51 1444-1451. (doi:10. 1053/meta.2002.34716)

Melnikova V, Raison D, Hardin-Pouzet H, Ugrumov M, Calas A \& GrangeMessent V 2006 Noradrenergic regulation of galanin expression in the supraoptic nucleus in the rat hypothalamus. An ex vivo study. Journal of Neuroscience Research 83 857-863. (doi:10.1002/jnr.20779)

Millington G 2007 The role of proopiomelanocortin (POMC) neurones in feeding behaviour. Nutrition and Metabolism 4 18. (doi:10.1186/17437075-4-18)

Moran T 2006 Gut peptide signaling in the controls of food intake. Obesity 14 250s-253s. (doi:10.1038/oby.2006.318)

Morash B, Li A, Murphy P, Wilkinson M \& Ur E 1999 Leptin gene expression in the brain and pituitary gland. Endocrinology $\mathbf{1 4 0}$ 5995-5998. (doi:10.1210/en.140.12.5995)

Morimoto R, Satoh F, Murakami O, Totsune K, Saruta M, Suzuki T, Sasano H, Ito $S$ \& Takahashi K 2008 Expression of peptide YY in human brain and pituitary tissues. Nutrition 24 878-884. (doi:10.1016/j.nut.2008.06.011)

Munday M \& Williamson D 1983 Diurnal variations in food intake and in lipogenesis in mammary gland and liver of lactating rats. Biochemical Journal 214 183-187.

Nakahara K, Hayashida T, Nakazato M, Kojima M, Hosoda H, Kangawa K \& Murakami N 2003 Effect of chronic treatments with ghrelin on milk secretion in lactating rats. Biochemical and Biophysical Research Communications 303 751-755. (doi:10.1016/S0006-291X(03)00414-5) 
Nakazato M, Murakami N, Date Y, Kojima M, Matsuo H, Kangawa K \& Matsukura S 2001 A role for ghrelin in the central regulation of feeding. Nature 409 194-198. (doi:10.1038/35051587)

Ohinata K, Inui A, Asakawa A, Wada K, Wada E \& Yoshikawa M 2002 Albutensin A and complement C3a decrease food intake in mice. Peptides 23 127-133. (doi:10.1016/S0196-9781(01)00588-5)

Ohinata K, Suetsugu K, Fujiwara Y \& Yoshikawa M 2007 Suppression of food intake by a complement C3a agonist [Trp5]-oryzatensin(5-9). Peptides 28 602-606. (doi:10.1016/i.peptides.2006.11.020)

Parker J \& Bloom S 2012 Hypothalamic neuropeptides and the regulation of appetite. Neuropharmacology 63 18-30. (doi:10.1016/j.neuropharm. 2012.02.004)

Pelleymounter M, Cullen M, Baker M, Hecht R, Winters D, Boone T \& Collins F 1995 Effects of the obese gene product on body weight regulation in ob/ob mice. Science 269 540-543. (doi:10.1126/science.7624776)

Pickavance L, Tadayyon M, Williams G \& Vernon R 1998 Lactation suppresses diurnal rhythm of serum leptin. Biochemical and Biophysical Research Communications 248 196-199. (doi:10.1006/bbrc.1998.8934)

Ricklin D, Hajishengallis G, Yang K \& Lambris J 2010 Complement: a key system for immune surveillance and homeostasis. Nature Immunology 11 785-797. (doi:10.1038/ni.1923)

Sakamoto T, Mori K, Miyazato M, Kangawa K, Sameshima H, Nakahara K \& Murakami N 2008 Involvement of neuromedin S in the oxytocin release response to suckling stimulus. Biochemical and Biophysical Research Communications 375 49-53. (doi:10.1016/j.bbrc.2008.07.124)

Sakurai T, Amemiya A, Ishii M, Matsuzaki I, Chemelli R, Tanaka H, Williams S, Richarson J, Kozlowski G, Wilson S et al. 1998 Orexins and orexin receptors: a family of hypothalamic neuropeptides and $\mathrm{G}$ protein-coupled receptors that regulate feeding behavior. Cell $\mathbf{9 2}$ 573-585. (doi:10.1016/S0092-8674(00)80949-6)

Schwartz MW 2006 Central nervous system regulation of food intake. Obesity 14 1s-8s. (doi:10.1038/oby.2006.275)

Schwartz MW, Seeley RJ, Campfield LA, Burn P \& Baskin DG 1996 Identification of targets of leptin action in rat hypothalamus. Journal of Clinical Investigation 98 1101-1106. (doi:10.1172/JCI118891)

Schwartz MW, Seeley RJ, Woods SC, Weigle DS, Campfield LA, Burn P \& Baskin DG 1997 Leptin increases hypothalamic pro-opiomelanocortin mRNA expression in the rostral arcuate nucleus. Diabetes $\mathbf{4 6}$ 2119-2123. (doi:10.2337/diab.46.12.2119)

Schwartz MW, Woods SC, Porte D, Seeley RJ \& Baskin DG 2000 Central nervous system control of food intake. Nature $\mathbf{4 0 4} 661-671$.

Smith MS 1993 Lactation alters neuropeptide-Y and proopiomelanocortin gene expression in the arcuate nucleus of the rat. Endocrinology $\mathbf{1 3 3}$ 1258-1265. (doi:10.1210/en.133.3.1258)

Smith PM \& Ferguson AV 2008 Neurophysiology of hunger and satiety. Developmental Disabilities Research Reviews 14 96-104. (doi:10.1002/ddrr.13)
Sun G, Narita K, Murata T, Honda K \& Higuchi T 2003 Orexin-A immunoreactivity and prepro-orexin mRNA expression in hyperphagic rats induced by hypothalamic lesions and lactation. Journal of Neuroendocrinology 15 51-60. (doi:10.1046/j.1365-2826.2003.00862.x)

Suzuki Y, Kurose Y, Takahashi H, Asakuma S, Azuma Y \& Kobayashi S 2010 The differences in feeding-inhibitory responses to peripheral and central leptin between non-lactating and lactating rats. Journal of Endocrinology 207 105-111. (doi:10.1677/JOE-09-0463)

Tartaglia LA, Dembski M, Weng X, Deng N, Culpepper J, Devos R, Richards GJ, Campfield LA, Clark FT, Deeds J et al. 1995 Identification and expression cloning of a leptin receptor, OB-R. Cell 83 1263-1271. (doi:10.1016/0092-8674(95)90151-5)

Taylor V, Patterson M, Ghatei M, Bloom S \& Wilson C 2009 Ghrelin and peptide YY (PYY) profiles in gastrointestinal tissues and the circulation of the rat during pregnancy and lactation. Peptides 30 2213-2220. (doi:10.1016/j.peptides.2009.09.022)

Thornton J, Cheung C, Clifton D \& Steiner R 1997 Regulation of hypothalamic proopiomelanocortin mRNA by leptin in ob/ob mice. Endocrinology 138 5063-5066. (doi:10.1210/en.138.11.5063)

Tong Q, Ye C-P, Jones J, Elmquist J \& Lowell B 2008 Synaptic release of GABA by AgRP neurons is required for normal regulation of energy balance. Nature Neuroscience 11 998-1000. (doi:10.1038/nn.2167)

Vernon RG \& Flint DJ 1984 Adipose tissue: metabolic adaptation during lactation. Symposium of the Zoological Society of London 51 119-145.

Wade G \& Schneider J 1992 Metabolic fuels and reproduction in female mammals. Neuroscience and Biobehavioral Reviews 16 235-272. (doi:10.1016/S0149-7634(05)80183-6)

Woodside B 2007 Prolactin and the hyperphagia of lactation. Physiology \& Behavior 91 375-382. (doi:10.1016/j.physbeh.2007.04.015)

Woodside B, Budin R, Wellman M \& Abizaid A 2012 Many mouths to feed: the control of food intake during lactation. Frontiers in Neuroendocrinology 33 301-314. (doi:10.1016/j.yfrne.2012.09.002)

Wren A, Seal L, Cohen M, Brynes A, Frost G, Murphy K, Dhillo W, Ghatei M \& Bloom S 2001 Ghrelin enhances appetite and increases food intake in humans. Journal of Clinical Endocrinology and Metabolism 86 5992-5995. (doi:10.1210/jc.86.12.5992)

Yamanaka A, Kunii K, Nambu T, Tsujino N, Sakai A, Matsuzaki I, Miwa Y, Goto K \& Sakurai T 2000 Orexin-induced food intake involves neuropeptide Y pathway. Brain Research 859 404-409. (doi:10.1016/ S0006-8993(00)02043-6)

Zwirska-Korczala K, Konturek SJ, Sodowski M, Wylezol M, Kuka D, Sowa P, Adamczyk-Sowa M, Kukla M, Berdowska A, Rehfeld JF et al. 2007 Basal and postprandial plasma levels of PYY, ghrelin, cholecystokinin, gastrin and insulin in women with moderate and morbid obesity and metabolic syndrome. Journal of Physiology and Pharmacology 58 13-35.

Received in final form 13 November 2013

Accepted 2 December 2013

Accepted Preprint published online 3 December 2013 http://jme.endocrinology-journals.org

DOI: 10.1530/JME-13-0015
C) 2014 The authors Printed in Great Britain
Published by Bioscientifica Ltd 